\title{
A Hidropolítica Platina no Contexto do Complexo Regional de Segurança da América do Sul: Entre o Conflito e a Cooperação (1960-1979)*
}

Fábio Albergaria de Queiroz**

\section{Introdução}

O planeta dispõe de aproximadamente 1,386 bilhão de $\mathrm{km}^{3}$ de água. Quase toda ela-97,5\% - é salgada. Dos 2,5\% de água doce, mais de $2 / 3$ estão indisponíveis para o consumo e, igualmente, para a maior parte dos usos industriais, pois estão contidos em glaciares e subsolos (CLARKE; KING, 2005, p. 20). Ademais, além de ser um recurso escasso, a água apresenta grande desigualdade em termos de distribuição geográfica, sendo, pois, sua disponibilidade muito variável nas diversas regiões do mundo. Tal cenário nos convida a refletir so-

\footnotetext{
* Artigo recebido em 3 de novembro de 2011 e aprovado para publicação em 19 de junho de 2012.

** Doutor em Relações Internacionais pela Universidade de Brasília (UnB) e professor no curso de Relações Internacionais da Universidade Católica de Brasília (UCB). E-mail: fabioaq@hotmail. com.
}

CONTEXTO INTERNACIONAL Rio de Janeiro, vol. 34, nº 2, julho/dezembro 2012, p. 573-616. 
bre os temas ligados aos recursos hídricos como fatores capazes de gerar instabilidade. Afinal, para responder às múltiplas exigências internas de um país, da dessedentação humana à geração de energia, são utilizadas águas que não provêm exclusivamente de dentro das fronteiras nacionais.

Além disso, é relevante o fato de que, dos rios compartilhados existentes, apenas cerca de $1 / 4$ tem sua utilização regulamentada por tratados em vigor, sendo que mais da metade desses tratados não preveem quaisquer mecanismos de solução de controvérsias (FERREIRA, 2003, p. 39).

Nesse complexo contexto em que os recursos hídricos figuram como importante referência nas relações internacionais, a América do Sul destaca-se como uma das maiores reservas de água doce do mundo, ostentando em seus domínios cerca de $26 \%$ do volume total disponível.

Assim, nesse panorama em que o compartilhamento de águas internacionais apresenta o potencial de ensejar relações de alta complexidade na medida em que as ações de um país podem comprometer os interesses de seus vizinhos, temos um quadro, aqui fazendo uso da terminologia cunhada por Elhance (1999, p. 13), de interdependência hidrológica. Esse fator ratifica a importância da adjacência e, por conseguinte, do nível de análise regional como o mais adequado para lidar com as questões de hidropolítica ${ }^{1}$ e segurança que venham a surgir entre aqueles que são os principais atores nesta inter-relação: os Estados (BUZAN et al., 1998, p. 199).

Em tal situação, o conceito de vulnerabilidade descrito por Keohane e Nye (1989, p. 12) ${ }^{2}$ como "a capacidade de reação de um Estado, considerando-se a disponibilidade e a dispendiosidade das alternativas que os atores possuem" se torna um elemento igualmente importante nas relações internacionais dos países que compartilham o uso e a gestão de recursos hídricos. 
Afinal, como pondera Le Prestre (2000, p. 442), a água pode aguçar situações conflitivas conforme: o grau de vulnerabilidade e dependência de cada país com relação aos seus múltiplos usos; o número de atores que reivindicam o acesso a ela; os recursos de poder de que dispõem esses atores; a existência de produtos substitutivos (inexistentes no presente); ou até mesmo o caráter simbólico que assume esse recurso em termos políticos, culturais e de identidade.

Com base nessas considerações, eis, então, a questão central a ser desenvolvida ao longo das próximas páginas. No contexto da hidropolítica regional, como a Bacia Platina, um dos principais sistemas hidrográficos do planeta, influenciou, e influencia, a conformação das relações internacionais no Complexo Regional de Segurança da América do Sul? Do problema levantado, subsidiariamente, delineia-se uma segunda questão: teríamos, no ambiente sul-americano, dinâmicas hidropolíticas intensas a ponto de tornar o uso compartilhado das águas platinas uma questão de segurança? Por quê?

Na busca de respostas para essas perguntas, partimos da hipótese de que, quanto maior for o grau de interdependência hidrológica entre os atores que compartilham os usos de um sistema hidrográfico, maior será a probabilidade de formação de Complexos Hidropolíticos. Vê-se, portanto, que utilizaremos como ferramenta conceitual o modelo descritivo dos Complexos Hidropolíticos. Trata-se de uma adaptação concebida nos moldes dos Complexos Regionais de Segurança para lidar com as externalidades que podem potencialmente surgir em torno do uso comum dos recursos hídricos.

Assim, para cumprir os objetivos propostos, num primeiro momento o artigo apresenta tal estrutura conceitual para, em seguida, verificar se, no caso do Complexo Regional de Segurança da América do Sul, há a confirmação da hipótese levantada por meio da identificação de um Complexo Hidropolítico construído a partir das dinâmicas originadas entre os atores que compartilham os recursos hídricos platinos. 


\title{
A Ampliação do Conceito de Segurança e a Teoria dos Complexos Regionais de Segurança
}

\begin{abstract}
A discussão sobre a ampliação do conceito de segurança tem nas contribuições da chamada Escola de Copenhague um ponto referencial emblemático. Sua abordagem abrangente oferece aos pesquisadores da área um arcabouço teórico alternativo à perspectiva tradicional ao ensejar a incorporação progressiva de novos temas e atores nos estudos em segurança a partir de uma estrutura conceitual própria. ${ }^{3}$ Então, considerando tal perspectiva, como definir o que vem a ser segurança?
\end{abstract}

De acordo com a Escola de Copenhague, segurança é "o movimento que leva a política para além das regras estabelecidas e enquadra a questão, ou como um tipo especial de política ou como um conjunto de ações que se executa acima dela" (BUZAN et al., 1998, p. 23-24). Nesse processo, denominado de securitização, o ator securitizador, diante de uma situação de ameaça, busca colocar o objeto a ser protegido (objeto referente) em um lócus de decisão imune às regras ordinárias do jogo político em que se justificaria, portanto, a utilização dos meios necessários para resolver o problema.

Cabe ressaltar que um dado assunto pode ser enquadrado em um amplo espectro que vai do não politizado (em que não é visto como um tópico que deva ser submetido ao debate público ou demande decisões em termos de segurança), passando pela politização (em que há o reconhecimento de que o tema é de interesse público e, portanto, objeto de decisão governamental e alocação de recursos) e indo, nos casos extremos, à condição de securitizado (que, como visto, requer o uso de medidas emergenciais, ainda que fora dos limites convencionais do processo político). 


\section{A Hidropolítica Platina no Contexto do Complexo Regional de Segurança...}

Há ainda o movimento inverso, a dessecuritização, que consiste em deslocar assuntos anteriormente qualificados como existencialmente ameaçados para o nível dos processos usuais de barganha e disputa da esfera política (BUZAN et al., 1998, p. 4). Cumpre também destacar que tipificar um assunto de acordo com essas estruturas conceituais não é uma prerrogativa exclusiva dos Estados, podendo, inclusive, ocorrer por intermédio da agência de atores outros como organizações intergovernamentais, comunidades epistêmicas, organizações não governamentais (ONGs) de alcance transnacional ou mesmo pela ação de movimentos sociais de natureza diversa (grupos nacionalistas, anti-imigração, antiglobalização etc.), só para citar alguns exemplos.

Esses processos revelam, então, que os critérios estabelecidos para definir determinado tema como sendo de segurança é uma construção social intersubjetiva e está diretamente relacionado à ênfase discursiva atribuída aos possíveis efeitos políticos substanciais de uma dada ameaça existencial a um objeto referente. Por isso, tal processo, denominado pelos autores como movimento de securitização, configura-se como uma negociação entre um agente securitizador e sua audiência em busca de legitimidade e permissão para desconsiderar as regras vigentes do jogo político ou, então, alterá-las.

Logo, essa análise corrobora a premissa defendida por BUZAN (1991, p. 60) de que o Estado não é um ator coerente e unitário em termos de percepção de ameaças à sua integridade, embora, por mais que existam divergências, haja sempre uma resultante, ainda que provisória, dos alinhamentos e coalizões políticas domésticas.

Assim, diferentemente da percepção neorrealista de ameaça "como algo essencialmente material e objetivo" (STAHL, 2007, p. 4), o grupo de Copenhague a apresenta, seguindo a mesma lógica da definição de segurança, como uma construção social. Essas observações são igualmente válidas para a análise de cenários hidropolíticos. 
Transpondo-as para esse campo de estudo, teríamos, analogicamente, a seguinte configuração:

\section{Quadro 1}

Aplicação do Modelo Teórico da Escola de Copenhague à Hidropolítica

\begin{tabular}{|c|c|c|}
\hline & Escola de Copenhague & Na Hidropolítica \\
\hline Objeto Referente & $\begin{array}{l}\text { Unidades de análise cuja } \\
\text { segurança/existência se } \\
\text { encontre ameaçada, ou } \\
\text { seja, apresentada como } \\
\text { tal por meio do discurso. }\end{array}$ & $\begin{array}{l}\text { Estabilidade política, } \\
\text { econômica, societal, territorial } \\
\text { e/ou ambiental de um Estado } \\
\text { por conta das ações de algum } \\
\text { ribeirinho em um determinado } \\
\text { curso hidrológico. }\end{array}$ \\
\hline $\begin{array}{c}\text { Atores } \\
\text { Securitizadores }\end{array}$ & $\begin{array}{l}\text { Atores que dispõem de } \\
\text { autoridade e/ou recursos } \\
\text { que Ihes autorizem } \\
\text { declarar determinado } \\
\text { objeto referente como } \\
\text { existencialmente } \\
\text { ameaçado. }\end{array}$ & $\begin{array}{l}\text { Normalmente os Estados que, } \\
\text { por meio de suas elites } \\
\text { decisórias, externam suas } \\
\text { percepções quanto a ameaças } \\
\text { setoriais em decorrência das } \\
\text { ações de algum ribeirinho em } \\
\text { um determinado curso } \\
\text { hidrológico. }\end{array}$ \\
\hline Atores Funcionais & $\begin{array}{l}\text { Atores que afetam a } \\
\text { dinâmica de um ou vários } \\
\text { setores, contudo, sem } \\
\text { atuar na condição de } \\
\text { objeto referente ou ator } \\
\text { securitizador. }\end{array}$ & $\begin{array}{l}\text { Terceiras partes que tenham } \\
\text { algum tipo de interesse no } \\
\text { desfecho da situação como: } \\
\text { Estados ribeirinhos pouco/não } \\
\text { afetados; organizações } \\
\text { intergovernamentais; ONGs, } \\
\text { comunidades ripícolas e } \\
\text { epistêmicas. }\end{array}$ \\
\hline
\end{tabular}

Fonte: Elaborado a partir de Buzan et al. (1998, p. 36).

\section{A Teoria dos Complexos Regionais de Segurança}

Além de propor a ampliação do conceito de segurança, a Escola de Copenhague trouxe outra grande contribuição à área ao destacar a importância das dinâmicas que ocorrem em um nível de análise intermediário, estabelecendo, como referência conceitual, o modelo descritivo dos Complexos Regionais de Segurança (CRS). 


\section{A Hidropolítica Platina no Contexto do}

Complexo Regional de Segurança...

Uma das premissas desse modelo pressupõe ser a proximidade geográfica uma variável determinante uma vez que as ameaças setoriais tendem a se mover mais facilmente entre distâncias menores. Por isso, como apontam Buzan e Wæver (2003, p. 27), considerar as relações de segurança a partir de um nível de análise subsistêmico, localizado entre o global e o local, é o que confere grande poder analítico à Teoria dos Complexos Regionais de Segurança.

Com a ampliação setorial e a introdução de novos atores, Buzan et al. (1998, p. 201) definiram-no como "um conjunto de unidades cujos principais processos de securitização, dessecuritização ou ambos estão tão interligados que seus problemas de segurança não podem ser razoavelmente analisados ou resolvidos de maneira isolada". Ainda assim, percebe-se que os CRS são concebidos a partir do Estado como unidade base de análise, isso porque estão presentes em todos os setores como atores e interlocutores centrais, regularidade esta que não ocorre com outras estruturas ontológicas como, por exemplo, a nação que pode ser importante no setor societal, mas não necessariamente no ambiental e/ou econômico. ${ }^{4}$

Vê-se, portanto, que os CRS resultam de interações simbióticas entre variáveis materiais e ideacionais como crenças, identidades, capacidades materiais, fronteiras, distribuição/percepção de poder, anarquia, polaridade e construção social, o que confere ao modelo maior alcance, consistência e densidade analítica. Outro ponto central nessa estrutura, uma das características distintivas de um CRS, está no fato de que os processos de securitização/dessecuritização e, por conseguinte, o grau de interdependência em segurança é notadamente mais intenso entre as unidades que o compõem do que entre estas e os atores externos ao complexo (BUZAN; WÆVER, 2003, p. 4).

A partir desse quadro geral, os autores delinearam duas possíveis formações em que são assimilados os atores e setores da agenda ampla de segurança: 1) Complexos Homogêneos, compostos por formas 
específicas de interação entre unidades similares (por exemplo, complexos militares formados por Estados); e 2) Complexos Heterogêneos, que agregam diferentes tipos de atores em dois ou mais setores (por exemplo, Estados, nações e empresas interagindo nos setores político, econômico e/ou societal).

Identificada a forte característica introspectiva das relações que definem um Complexo, surge outra variável intrinsecamente ligada a ela e igualmente importante nesta estrutura: as relações de amizade e inimizade entre suas unidades a partir dos processos interativos de formação de identidades. Segundo os padrões de amizade-inimizade, resultantes de um relacionamento histórico-social dinâmico, os CRS podem ser classificados a partir de um contínuo com um polo positivo e outro negativo.

Dessa forma, no extremo positivo, as relações de amizade entre as unidades são preponderantes e dão ensejo à formação de uma Comunidade de Segurança em que as expectativas de mudança são sempre pacíficas (DEUTSCH et al., 1957). ${ }^{5}$ Por outro lado, no extremo negativo as relações são tencionadas pela desconfiança e pelo medo, e resultam em formações conflituosas. Na zona intermediária entre os dois polos, é possível observar a formação de regimes de segurança, um híbrido entre as referências ontológicas anteriores.

Assim, com base nas proposições da Escola de Copenhague, podemos sintetizar a estruturação de um CRS a partir de três tipos de relações principais: 1) a distribuição de poder entre as unidades da região (polaridade), o que pressupõe uma estrutura anárquica composta por duas ou mais unidades autônomas; 2) os padrões de amizade/inimizade entre os atores desse complexo nos setores militar, político, societal, econômico e/ou ambiental; e 3) as relações de poder com atores externos à região, especialmente com relação à superpotência e às grandes potências. 
A partir desse conjunto de variáveis - estrutura anárquica, polaridade, construção social e fronteiras -, Buzan e Wæver (2003, p. 445-446) identificaram a existência de onze CRS: América do Norte, América do Sul, Europa, Pós-URSS, Oriente Médio, África Ocidental, África Central, Chifre da África, África Austral, Sul da Ásia e Leste Asiático. Ainda de acordo esta tipologia, a América do Sul é classificada como um CRS do tipo padrão, marcado pela presença de mais de uma potência regional. Ademais, faz-se importante ressaltar que este CRS é composto por duas estruturas sub-regionais: o Subcomplexo de Segurança do Cone Sul, alvo deste estudo, formado por Argentina, Bolívia, Brasil, Chile, Paraguai e Uruguai, e o Subcomplexo de Segurança Andino, que reúne Peru, Equador, Colômbia, Venezuela e Guiana. ${ }^{6}$

\section{A Hidropolítica e a Teoria dos Complexos Regionais de Segurança}

Um olhar panorâmico sobre o cenário da hidropolítica internacional sinaliza-nos haver regiões em que a água transparece, nos termos da Escola de Copenhague, como um assunto claramente securitizado. Foi assim, na tentativa de buscar evidências sobre possíveis conexões entre as dinâmicas originadas no contexto específico da bacia dos rios Tigre e Eufrates e a agenda de segurança do CRS do Oriente Médio, que Schulz (1995), recorrendo ao auxílio da Teoria dos Complexos Regionais de Segurança, formulou o conceito de Complexo Hidropolítico de Segurança (CHS). Segundo o autor, trata-se de uma forma especial que surge quando "um conjunto de Estados ribeirinhos passa a perceber o uso de sistemas hidrográficos compartilhados como uma questão prioritária de segurança nacional" (SCHULZ, 1995, p. 97).

Ressalte-se, ainda, que tal cenário pode adquirir contornos mais agudos se houver um histórico de inimizade entre os países do Complexo 
e/ou, como acrescenta Bächler (1995 apud FERREIRA, 2003, p. 50), se forem de pouca efetividade (ou inexistentes) os mecanismos de integração, de cooperação e de solução de controvérsias entre os ribeirinhos, aumentando, dessa forma, a possibilidade de que esses atores recorram a meios extraordinários, inclusive o uso da força, para lidar com as demandas existentes. Foi nesse contexto peculiar que Schulz (1995, p. 97) identificou a existência de um CHS formado por Turquia, Iraque e Síria.

Basicamente, este CHS se erigiu com base na identificação de uma intrínseca interdependência entre as agendas de segurança dos três países que o integram, derivada dos efeitos transfronteiriços ocasionados pelo uso compartilhado das águas da Bacia do Tigre-Eufrates com relação à construção de barragens, controle do fluxo de água, salinização e geração de energia hidrelétrica. A situação assumiu uma dimensão ainda mais intensa por ser o Complexo Hidropolítico de Segurança do Tigre-Eufrates, assim rotulado por Schulz, uma região caracterizada por um quadro de grave déficit hídrico (BUZAN et. al., 1998, p. 90), exacerbando, dessa maneira, a percepção de que, no caso aludido, a hidropolítica regional figura como uma prioridade estratégica.

Não obstante sua relevância, o modelo desenvolvido por Schulz possui limitações quanto à sua aplicabilidade em situações que não apresentem a mesma densidade conflitiva encontrada nos casos tomados por ele como objeto de estudo. Como visto, o CHS, tal qual proposto, toma forma a partir de situações de tensão, em cenários propensos à securitização da água em seu espectro mais negativo, ou seja, considerando-se o uso da força. Além disso, o modelo desenvolveu-se tendo como foco o compartilhamento de águas superficiais.

Assim, surgem alguns pontos importantes para reflexão. Primeiramente, seria possível ter estruturas similares que contemplem uma situação de interdependência hidrológica, mas em um contexto de 


\section{A Hidropolítica Platina no Contexto do Complexo Regional de Segurança...}

cooperação? Seria também possível que as dinâmicas originadas a partir do compartilhamento de águas subterrâneas, como os aquíferos, importantes reservas de água doce, ensejem a formação de Complexos?

Tomando essas considerações, e tendo como ponto referencial o trabalho de Schulz e as contribuições da Escola de Copenhague, autores como Allan (2001) e Turton (2003) aperfeiçoaram o modelo original ao incorporarem a ele novas dimensões de forma a dotá-lo de maior capacidade explicativa. Para tal, foi introduzida a premissa construtivista de amizade/inimizade em um continuиm mais amplo como eixo definidor das dinâmicas de segurança, bem como se atribuiu maior destaque para o compartilhamento de sistemas hídricos subterrâneos, e não apenas superficiais, como referência para explicar o papel da hidropolítica na agenda política de sub-regiões como a África Ocidental, Meridional e o Oriente Médio.

Assim, a partir desses testes empíricos, Allan (2001; 2002) e Turton $(2003 ; 2008)$ passaram a contemplar a existência do que eles genericamente chamaram de Complexos Hidropolíticos naquelas regiões em que

[...] a dependência de sistemas hídricos compartilhados - tanto superficiais como subterrâneos - é de tal natureza estratégica que essa dependência começa a influenciar as relações interestatais de uma forma perceptível, seja para um quadro potencial de cooperação (amizade) e/ou de competição (inimizade) (TURTON, 2008, p. 188).

Por conseguinte, os autores convencionaram que, se as relações entre os ribeirinhos tenderem ao fortalecimento dos laços de amizade e da cooperação mútua, têm-se, como resultante, o esboço de um Complexo Hidropolítico $(\mathrm{CH})$. Por outro lado, se estas dinâmicas indicarem um cenário de inimizade e tensão, como no caso envolvendo 
Turquia, Iraque e Síria, tem-se, tal qual definiu Schulz, a formação de um Complexo Hidropolítico de Segurança (CHS). Portanto, de acordo com esta tipologia, o CHS passou a ser classificado como um tipo distinto de Complexo Hidropolítico.

Dessa forma, o modelo dos $\mathrm{CH} / \mathrm{CHS}$, originalmente apresentado como estrutura integrante de um Complexo Regional de Segurança do tipo heterogêneo (TURTON, 2001, p. 19), torna possível verificar tanto a existência de clivagens multissetoriais (sobremodo nos casos de relações horizontais) como conexões entre diferentes níveis de análise (relações verticais) em cenários de elevada interdependência hidrológica, sejam eles marcados por um continuum de cooperação ou de conflito. Dito isso, vamos, então, ao nosso objeto de análise: a Bacia Platina.

\section{A Hidropolítica na Bacia do Prata: Entre o Conflito e a Cooperação (1966-1979)}

Historicamente, a Bacia do Prata demonstrou ser uma região sensível não apenas para os países que a compõem, mas de forma geral para a manutenção do equilíbrio de poder na América do Sul. As relações internacionais na região experimentaram, ao longo da história, alternâncias entre períodos de antagonismos, conflitos, desconfianças e cooperação. Abrangendo os territórios de cinco países - Argentina, Bolívia, Brasil, Paraguai e Uruguai -, esta bacia, com uma área de 3,1 milhões de $\mathrm{km}^{2}$ (equivalente a $17 \%$ da superfície da América do Sul), é a segunda maior estrutura hidrográfica do continente, sendo superada apenas pela Bacia Amazônica.

O principal rio da Bacia é o Paraná, com 3.780 km, acompanhado de seus maiores afluentes: o Paraguai, com 2.620 km, e o Uruguai, com $1.600 \mathrm{~km}$, todos eles nascendo em território brasileiro. O rio Paraná se torna rio da Prata ao receber o rio Uruguai, pouco antes de desem- 


\section{Figura 1}

Bacia do Prata

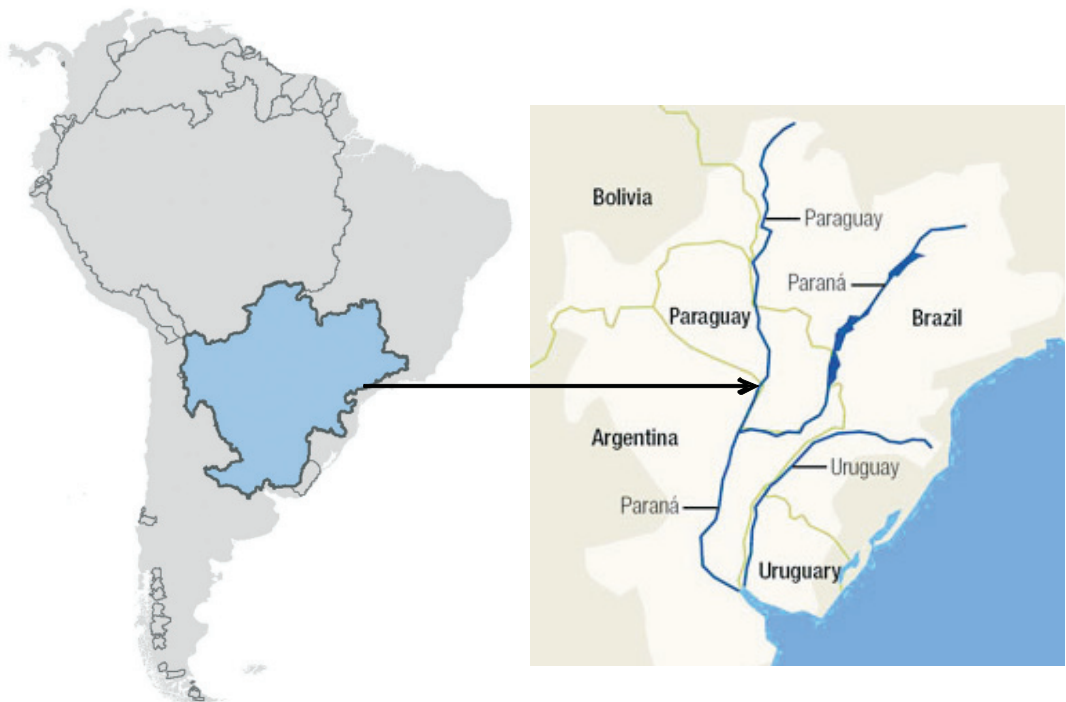

bocar no Oceano Atlântico, como demonstram as ilustrações seguintes.

A magnitude dos números que descrevem esse sistema hidrográfico evidencia sua importância estratégica. Nele, são gerados $70 \%$ do PIB dos cinco países que o integram e onde vive cerca de $50 \%$ da população dos mesmos (ANA, 2001, p. 5). A estrutura hidráulica instalada ao longo da bacia constitui a principal fonte de abastecimento energético do polo produtivo mais dinâmico da América do Sul, sendo que Itaipu, a maior usina hidrelétrica do mundo em geração de energia, produz mais de 90 bilhões de $\mathrm{kWh}$, o que corresponde a $20 \%$ de toda a energia consumida no Brasil e quase $92 \%$ da demanda energética paraguaia (PINTO, 2009, p. 16-18). ${ }^{7}$ Além disso, seus principais rios e afluentes proporcionam 15 mil quilômetros de vias navegáveis, constituindo a única saída natural para o Oceano Atlântico para Bolí- 
via e Paraguai, bem como para importantes regiões do Brasil e da Argentina (PINTO, 2009, p. 18).

Com relação à exploração energética, a construção da Usina Binacional de Itaipu, entre Brasil e Paraguai, pôs a hidropolítica como assunto de destaque na agenda das relações internacionais platinas em um período notadamente marcado, segundo Lima (1986), por um perfil comportamental hegemônico por parte do Brasil. Nesse aspecto, o empreendimento de Itaipu trouxe desdobramentos em campos distintos, envolvendo não apenas seus sócios, mas também a Argentina, reflexo de problemas passados não resolvidos e desafios geopolíticos regionais imersos em desconfiança.

Com relação ao Paraguai, Itaipu fez emergir questões de fronteiras latentes desde o fim da Guerra contra a Tríplice Aliança formada por Brasil, Argentina e Uruguai (1864-1870). Já a Argentina via nessa parceria a expansão da influência geopolítica brasileira no Cone Sul e, por conseguinte, a diminuição da sua (PECEQUILO; HAGE, 2007 , p. 2). Segundo os autores, ainda hoje a exploração hidroenergética ilustra uma complexa interdependência com potencial de gerar externalidades multidimensionais para a região, demonstrando, portanto, ser um assunto que demanda constante atenção.

Dado o exposto, observa-se que a relevância da hidropolítica sul-americana aponta para questões singulares que conferem ao tema da gestão integrada dos recursos hídricos papel estratégico no contexto das relações internacionais da região. Essa situação demanda uma estrutura normativa capaz de estabelecer regras que institucionalizem responsabilidades e deveres comuns, já que grande parte dos recursos hídricos é compartilhada. Entretanto, a formação de tal aparato institucional é tarefa complexa, pois pode conflitar com os interesses soberanos de cada um dos Estados ribeirinhos, como veremos adiante. 


\section{A Hidropolítica Platina no Contexto do Complexo Regional de Segurança...}

\section{As Dinâmicas Hidropolíticas na Bacia Platina}

Se a navegação é, tradicionalmente, um dos usos econômico-estratégicos mais antigos e importantes do sistema hidrográfico platino, no decorrer do século XX o aproveitamento de suas águas para fins de produção energética também se destacou sobremodo, ocupando lugar de destaque. ${ }^{8}$ Mesmo periódicos pouco afetos ao contexto do Cone Sul, como o diário turco Beyoglu, destacavam a capacidade hidroenergética da Bacia Platina. Neste aspecto, sua edição de 28 de julho de 1944 trouxe interessante artigo sobre os recursos hídricos sul-americanos e as possíveis implicações geopolíticas conexas à sua exploração (LES RESERVES..., 1944).

Referente ao futuro dos projetos hidráulicos no Cone Sul, o artigo afirmou que a Argentina se encontrava em situação desfavorável, indicando, também, que para remediar esse inconveniente o país se abasteceria com a energia da Bolívia, um "feudo" circunscrito à esfera de influência de Buenos Aires que pagava seu tributo em petróleo e que esperava completá-lo, em breve, com a energia de suas cachoeiras.

Quanto ao Brasil, o texto citou apenas as possibilidades de exploração no vale do São Francisco. É curioso que em nenhum momento tenha sido feito sequer um apontamento sobre Iguaçu e as Sete Quedas, segundo C. de Ouro Preto - diplomata que reportou o conteúdo da matéria ao chanceler Oswaldo Aranha-, por talvez o articulista achar mais prudente não abordar um assunto tão sensível em torno do qual as chancelarias platinas perigosamente se defrontavam. ${ }^{9}$

O fato é que a execução de grandes projetos hidráulicos para fins de exploração energética em águas compartilhadas só veio a florescer nesse espaço nas décadas seguintes ao término da Segunda Guerra Mundial. Sobre as primeiras considerações acerca das implicações estratégicas de tais empreendimentos, um relatório informativo pro- 
duzido ainda no ano de 1952 por um grupo de técnicos brasileiros designados para avaliar o potencial energético de Sete Quedas/Saltos de Guairá afirmou que:

Desde logo, parece fora de dúvida que, sob os ângulos político, econômico e, também, militar, seria útil aos interesses brasileiros que o principal centro econômico do Paraguai se tornasse dependente perene, quanto à energia elétrica, de suprimento fornecido, com exclusividade, por usina construída pelo Brasil na fronteira comum no rio Paraná. Nesse centro econômico, situam-se a própria capital, Assunção, e a cadeia de cidades que se estende até Villarrica, compreendida, também, a importante região do Paraguarí. Sob este aspecto, há óbvia vantagem em se admitir preferência por Guairá, por excluir de vez a inconveniente presença argentina, próxima ou futura, na matéria. Instalada a usina, com a respectiva linha de transmissão para o centro econômico paraguaio, este dificilmente comportaria a instalação, no futuro, para concorrência, de uma eventual segunda linha vinda de Iguaçu, com inevitável participação argentina. ${ }^{10}$

Corroborando o documento citado, em telegrama expedido pela Embaixada brasileira em Assunção, datado de 25 de julho de 1952, o embaixador Brasiliano Americano Freire tratou de informar ao Ministério das Relações Exteriores que a oportunidade ora em curso deveria ser aproveitada com a máxima brevidade uma vez que o Paraguai - dada a precariedade e o excessivo custo de produção de sua energia elétrica, que era toda de origem térmica - estava vivamente interessado na utilização de suas quedas d'água para substituir o atual modelo por outro mais seguro e econômico. ${ }^{11}$

Todavia, foi no início dos anos 1960 que o Brasil, motivado pela expansão de sua economia e pelo concomitante aumento na demanda 
por energia, entabulou estudos para o aproveitamento hidrelétrico do rio Paraná no trecho contíguo com o Paraguai. ${ }^{12} \mathrm{O}$ problema era que a ideia inicial do Brasil de fazer uso exclusivo do rio Paraná, desconsiderando-se o regime de condomínio de suas águas, soou como um atentado à soberania do Paraguai, trazendo à tona, como dito, problemas fronteiriços latentes desde o século XIX (PEREIRA, 1974, p. $51) .{ }^{13}$

Por isso, uma das primeiras medidas tomadas pelo presidente João Goulart (1961-1964) para tentar remediar a iminente crise diplomática que ensaiava eclodir, foi propor ao presidente paraguaio, Alfredo Stroessner, um plano conjunto de aproveitamento hidrelétrico do rio Paraná, iniciativa que ocorreu no dia 19 de janeiro de 1964, pouco mais de dois meses antes da derrubada de João Goulart do poder.

Contudo, com o fim antecipado do mandato de Goulart e a chegada dos militares ao poder, em 31 de março de 1964, o rumo das negociações mudou. O primeiro passo para lidar com esse quadro de incerteza e desconfianças mútuas se deu no governo Castello Branco (1964-1967), o primeiro do regime militar no Brasil (1964-1985) que tinha como uma de suas metas fazer do país uma potência média. Para isso, era preciso intensificar o crescimento econômico e a geração de energia que, como dito, era essencial para que esses planos tivessem êxito. Mas como fazê-lo? Como superar as desconfianças e as disputas territoriais do passado?

A posse do engenheiro Otávio Marcondes Ferraz como presidente da Eletrobrás, a agência estatal responsável pela gestão do setor energético, polarizou as discussões em torno do assunto no país. ${ }^{14}$ Ele era contrário à ideia de construção de uma usina binacional em Sete Quedas e defendia o desvio do rio Paraná a fim de que o aproveitamento de suas águas fosse feito exclusivamente em território brasileiro.

Marcondes Ferraz defendia a abertura de um canal de $60 \mathrm{~km}$ para desviar as águas acima de Sete Quedas para o lado brasileiro, devol- 
vendo-as, bem adiante, ao leito natural, proposição esta que gerou reações imediatas tanto no Brasil quanto no Paraguai. Dessa forma, os embates diplomáticos referentes ao aproveitamento energético nos rios platinos e às suas implicações geopolíticas seguiram marcados por muitas divergências e troca de notas oficiais, algumas delas notadamente em tom colérico, reflexo da inegável complexidade que envolvia o tema.

Por exemplo, em uma das declarações mais polêmicas atribuídas ao chanceler paraguaio, Raúl Sapena Pastor, e amplamente noticiada em Assunção, ele teria afirmado que a América conhecia muito bem a situação dos dois países quanto à questão fronteiriça, e que o Brasil agia por motivações artificiais, ao que prontamente respondeu o chanceler Juracy Magalhães:

[...] lamento a falta de serenidade com que sua Excelência trata um problema de extrema importância para as relações entre seu país e o Brasil. Não descerei à polêmica que, parece, sua Excelência deseja. Nem pretendo comparar os dois ilustres Governos responsáveis pelos destinos das duas grandes nações amigas, as quais não se tornarão inimigas pelos erros cometidos por alguns de seus dirigentes. Se de qualquer forma eu agravasse o povo paraguaio, haveria de penitenciar-me sempre de tão injusta atitude [...]. A causa brasileira é justa e, por isso, nos inspira completa tranquilidade. De minha boca jamais partiria uma frase como a que se contém no arrazoado divulgado pela imprensa e atribuída ao Senhor Sapena Pastor [...] não preciso refutar tal declaração em nome do Governo brasileiro, basta entregá-la ao julgamento da História. ${ }^{15}$

Foi somente em 1966, após muitas deliberações, que Juracy Magalhães finalmente externou ao governo paraguaio a intenção do Brasil 


\section{A Hidropolítica Platina no Contexto do Complexo Regional de Segurança...}

em iniciar um projeto conjunto em um futuro aproveitamento hidrelétrico dos Saltos de Guairá/Sete Quedas, o que foi considerado em Assunção como um progresso apreciável para a solução das divergências.

Esse imbróglio diplomático era acompanhado por Buenos Aires com muita preocupação, haja vista ser a Argentina um ribeirinho de jusante $\mathrm{e}^{16} \mathrm{e}$, igualmente, um grande interessado no potencial hidrelétrico do rio Paraná. Assim, independentemente de ser um projeto exclusivamente brasileiro ou binacional, com ou sem desvio de águas, a preocupação não deixava de ser a mesma uma vez que, consolidado o projeto, a Argentina estaria perigosamente vulnerável às pretensões brasileiras.

Desta forma, na tentativa de limitar a atuação do Brasil na Bacia do Prata, o presidente argentino Arturo Illia (1963-1966) propôs, sob a alegação de buscar alternativas viáveis para o desenvolvimento regional, a realização de um encontro entre as cinco chancelarias platinas para discutir o esboço de um plano para a integração física da bacia, bem como para o aproveitamento de seus recursos naturais. ${ }^{17}$

De fato, as hostilidades prevalecentes entre Brasil e Argentina quanto à incompatibilidade de seus projetos de aproveitamento hidrelétrico contribuíram para marcar o período como uma fase predominantemente tensa nas relações internacionais platinas, com o Paraguai atuando como "fiel da balança".

Assim, na geopolítica sul-americana de então, vemos os Estados platinos percebendo-se como ameaças potenciais e, no entanto, buscando, ainda que sob veladas suspicácias, evitar uma escalada conflituosa entre eles por meio da cooperação, apropriadamente definida por Keohane (2005) como "um intenso processo político de ajustes mútuos em uma situação real ou potencial de desacordo". 


\section{A Ata de Iguaçu e a Construção de um Regime Hidropolítico Platino (1966-1970)}

Em 1966, foi assinada a Ata de Iguaçu, ou Ata das Cataratas, iniciativa considerada o marco inicial que mais tarde daria origem ao Tratado de Itaipu, artífice daquela que seria a maior hidrelétrica do mundo. Por meio desse documento, os ministros das Relações Exteriores do Brasil, Juracy Magalhães, e do Paraguai, Sapena Pastor, concordaram em criar uma Comissão Técnica Mista entre os dois ribeirinhos para a realização de estudos acerca da viabilidade de exploração dos recursos hídricos da Bacia e para acordos preferenciais de venda de energia. $^{18}$

Como dito, a Argentina, temendo ficar à parte das negociações e, ao mesmo tempo, vendo a balança de poder definitivamente pendendo em favor do Brasil, organizou em Buenos Aires, em 27 de janeiro de 1967, uma reunião com os ministros das Relações Exteriores dos Estados ribeirinhos da Bacia do Prata. O encontro tinha, oficialmente, o objetivo de estudar os problemas comuns da área, com vistas a promover o pleno aproveitamento dos recursos naturais da região e o seu desenvolvimento econômico em benefício das populações ribeirinhas, bem como rever e resolver os problemas jurídicos relativos ao uso do sistema hidrográfico do Prata.

Oportunamente, a Argentina também demonstrou todo seu ressentimento com o projeto brasileiro-paraguaio, que, de acordo com o item IV da Ata de Iguaçu, excluía qualquer participação daquele país no projeto, bem como a possibilidade de usufruir da energia que seria gerada pela futura usina. Por outro lado, o encontro também evidenciou que, sem a participação da Argentina, qualquer iniciativa de aproveitamento energético seria inviável. Buenos Aires também defendia sua proposta de criar uma usina a jusante de Itaipu: a hidrelé- 


\section{A Hidropolítica Platina no Contexto do}

Complexo Regional de Segurança...

trica de Corpus, em parceria com o Paraguai (PEREIRA, 1974, p. 70).

Considerando-se então que os objetivos da Argentina, por um lado, e do consórcio brasileiro-paraguaio, do outro, eram muito divergentes, logo se percebeu que a adoção de normas comuns para a utilização dos recursos da Bacia não seria tarefa fácil (CAUBET, 2006, p. 124). Não obstante o latente cenário de tensão, na Reunião de Chanceleres de Buenos Aires estabeleceu-se uma agenda preliminar na qual foram definidos os objetivos fundamentais de uma ação conjunta dos países platinos para o desenvolvimento regional.

Para viabilizá-la, decidiu-se também pela criação de um Comitê Intergovernamental Coordenador (CIC) encarregado de centralizar as informações sobre a bacia e de coordenar a ação conjunta dos cinco países em parceria com as agências nacionais especializadas de cada um (CAUBET, 1989, p. 53-54).

Logo em seguida, em 1968, na Reunião de Chanceleres realizada em Santa Cruz de la Sierra (Bolívia), foi assinada uma ata estabelecendo os primeiros contornos jurídicos do Sistema da Bacia do Prata. Ainda nesta reunião, aprovou-se o estatuto do CIC que ficou incumbido de preparar e apresentar, na reunião do ano seguinte, o primeiro esboço de um tratado com o objetivo de institucionalizar as relações hidropolíticas na Bacia do Prata (CAUBET, 1989, p. 55).

Apesar dos esforços para se criar mecanismos que viabilizassem a gestão conjunta dos recursos da Bacia, vários percalços surgiram. Na medida em que as negociações avançavam, afluía um mordaz sentimento antibrasileiro em alguns importantes setores paraguaios, especialmente no segmento universitário, tendo como base de suas queixas a posse brasileira da Ilha de Itaipu, conforme estabelecido pelo documento de Cotegipe em 1872 (PECEQUILO; HAGE, 2007). 
Como mencionado, este era um documento de urgência ao qual faltava certa precisão geográfica. Todavia, estudos constataram que a área era de propriedade paraguaia desde antes da guerra de 1865. Naquele momento, não só no Paraguai, mas em boa parte da América do Sul, considerava-se o Brasil, apesar de seu status de grande nação, um país indiferente à sorte dos vizinhos, sem princípio de unidade (PECEQUILO; HAGE, 2007).

Divergências e desconfianças à parte, finalmente, no dia 23 de abril de 1969, durante a III Reunião de Chanceleres, realizado na cidade de Brasília, foi assinado o Tratado da Bacia do Prata, ou Tratado de Brasília, que entrou em vigor em 14 de agosto de 1970. Com objetivos amplos, explicitados em apenas oito artigos, o Tratado da Bacia do Prata constituiu um acordo quadro que foi se tornando operacional através de uma série de outros acordos e resoluções complementares, resultantes das Reuniões de Chanceleres que se consolidaram, de fato, como uma importante instância decisória.

O artigo primeiro do Tratado resumia bem o seu teor geral. Atestava que a água poderia, e deveria, ser utilizada para diversas finalidades, mas nenhum uso poderia ser feito em detrimento dos demais países, fosse em prejuízo da quantidade ou da qualidade da água. Assim, vemos no Tratado da Bacia do Prata o nascimento de um regime internacional erigido à base de conjuntos de princípios, normas e procedimentos decisórios, implícitos ou explícitos, ao redor dos quais converge a agência coordenada dos atores que integram a Bacia do Prata em prol de benefícios mútuos, ainda que de forma bastante incipiente e sujeita a percepções conflitantes quanto a vencidos e vencedores. Ele demonstrou, também, o quão politizada é a questão hídrica na região e, consequentemente, o papel central que o assunto ocupa na agenda regional de segurança.

Entretanto, apesar do Tratado, muitos conflitos de interesse se seguiram a ele com relação à construção de usinas hidrelétricas, assunto 


\section{A Hidropolítica Platina no Contexto do}

Complexo Regional de Segurança...

que continuou como um ponto nevrálgico nas relações internacionais do Cone Sul e, por conseguinte, no jogo de poder regional. Afinal, não se tratava apenas da produção de energia, mas de um enfrentamento continuado entre Brasil e Argentina, com o Paraguai desempenhando papel de suma importância nesse contexto, o que atestou, pois, sua privilegiada condição geopolítica, apesar de ser economicamente um dos países mais frágeis da região.

\section{- Complexo Hidroenergético Platino}

A construção da Usina Binacional de Itaipu, resultado das intensas negociações que se arrastaram durante a segunda metade da década de 1960 entre brasileiros e paraguaios, tornou realidade a ideia de apagar o litígio fronteiriço entre os dois países "com água”. Apesar das citadas manifestações contrárias ao empreendimento, também é fato que Itaipu encontrou amparo em vários segmentos no Paraguai, como o da construção civil, que via nele uma oportunidade singular de alavancar o setor. De forma geral, os principais periódicos da época saudavam com entusiasmo o que foi noticiado como fato histórico.

Como dissera Stroessner em discurso pronunciado no ato de troca dos instrumentos de ratificação do Tratado de Itaipu, a obra binacional era, depois da independência nacional, a maior realização da história paraguaia. Na mesma direção, o ministro da Indústria e Comércio do Paraguai, Delfin Ugarte Centurión, declarou ao periódico La Tribuna que:

[...] o curso da história econômica paraguaia está mudando com a obra de Itaipu. A declaração conjunta firmada pelos presidentes Alfredo Stroessner e Emílio Garrastazu Médici avança rapidamente e é um verdadeiro tratado de cooperação econômica. Encontramos nas autoridades brasileiras uma boa disposição, ca- 
Fábio Albergaria de Queiroz

racterística da tradicional conduta com que o Brasil sempre conduziu suas negociações com o Paraguai (UGARTE..., 1973, p. 5).

Em entrevista à revista Ñande, outra destacada autoridade nacional, o general Marcial Samaniego, ministro de Obras Públicas e Comunicações de Stroessner, assinalou, além dos impactos econômicos do empreendimento, a importância geopolítica de Itaipu para o país, avaliando que um de seus aspectos ditos transcendentais era de que:

[...] não obstante as inegáveis diferenças em termos de potencial humano, extensão territorial e capacidade financeira que favorecem o Brasil, o Paraguai, ao associar-se a este país na empreitada de Itaipu, alçou-se ao mesmo nível, no pleno exercício de sua soberania e em igualdade de direitos (ITAIPU..., 1973, p. 24).

Assim, observa-se que, apesar de o Estado não ser um ente coeso e unitário em termos de percepções de ameaças à sua integridade, a essência do discurso de boa parte da elite decisória guarani apontava para um alinhamento favorável em relação à parceria com o Brasil. ${ }^{19}$

Vê-se, com efeito, que Itaipu era uma verdadeira obra de "engenharia diplomática" concebida pelo Itamaraty e amparada pela elite decisória brasileira. O longo cumprimento entre Stroessner e Gibson Barboza ao final da cerimônia de troca dos instrumentos de ratificação apenas confirmou o que todos viram e ouviram: estava consumada Itaipu, a obra que o chanceler paraguaio Sapena Pastor qualificara naquele momento como "tão grandiosa que sua magnitude não podia ser interpretada, nem mesmo com muita imaginação" (UGARTE..., 1973, p. 6).

Em suma, a assinatura do Tratado de Itaipu resolveu duas questões fundamentais. Primeiramente, tranquilizou o Paraguai em sua contestação a respeito da disputa fronteiriça com o Brasil. Como a devolução da Ilha de Itaipu por parte do Brasil estava fora de cogitação, as 


\section{A Hidropolítica Platina no Contexto do Complexo Regional de Segurança...}

duas chancelarias resolveram dar vida a um empreendimento de caráter binacional, que atendesse às demandas territoriais paraguaias como uma forma de compensação. Assim, em 17 de maio de 1974, foi criada a Binacional Itaipu, entidade responsável pelo gerenciamento da construção da usina na área de disputa.

Além dos aspectos diplomáticos, Itaipu serviu aos propósitos econômicos e geopolíticos brasileiros dando-lhe conforto energético em um momento em que o país apresentava sinais de forte crescimento pela grande entrada de capital internacional e pela expansão de seu parque industrial e de sua infraestrutura de base (PECEQUILO; HAGE, 2007).

Em contrapartida, para a Argentina, as vantagens obtidas pelo Brasil não seriam somente essas: como previamente dito, Buenos Aires via com muitas ressalvas a política brasileira para o Paraguai, pois esta reforçava sua presença geopolítica no Cone Sul. Além de tornar os ribeirinhos menores em satélites em sua órbita de influência, o incremento do poder brasileiro era percebido como uma diminuição do argentino.

Em seus esforços para mudar a situação, a Argentina trabalhou para que no tratado fosse feita uma emenda que contemplasse o direito à consulta prévia, cabendo às partes interessadas, inclusive a própria Argentina, julgar a natureza e os efeitos das atividades realizadas. Assim, caso houvesse a indicação de que os empreendimentos brasileiro-paraguaios fossem causar algum dano à Argentina, os ribeirinhos deveriam consultá-la previamente antes de iniciar qualquer ação.

Em contraofensiva, o Brasil refutou a proposta argentina ao sustentar que nenhum Estado estava obrigado a suprir informação em condições tais que, a seu juízo fundamentado, pudesse prejudicar sua segurança nacional, o seu desenvolvimento econômico ou os seus esforços para melhoria do meio ambiente. Por conta dos fatos narrados, ao longo da década de 1970 a diplomacia brasileira teve de gerenciar enorme crise com a Argentina, que se mobilizou em diversas instân- 
cias, inclusive na Assembleia Geral das Nações Unidas, para impedir a construção de Itaipu enquanto, paralelamente, articulava o projeto da hidrelétrica de Corpus com o Paraguai.

Apesar do momento turbulento, ao ser interpelado sobre o tema, Mário Gibson Barboza declarou em 1973, em entrevista à revista Veja, que "por mais de uma vez já afirmei que a amizade inequívoca, franca e leal entre o Brasil e a Argentina é um imperativo histórico. Não considero que haja qualquer problema entre os dois países" (apud UM ENTENDIMENTO..., 1973).

No entanto, na prática, o tema Corpus/Itaipu seguia crescendo em dramaticidade. No dia 12 de julho de 1977, quando o presidente paraguaio Alfredo Stroessner foi ao Rio de Janeiro conferenciar com o general Ernesto Geisel (não por acaso, apenas dez dias antes da visita do presidente argentino Jorge Videla a Assunção), o chanceler Azeredo da Silveira declarou que o Brasil não poderia admitir a construção da hidrelétrica de Corpus na cota desejada pela Argentina, porque isso significaria abrir mão da soberania nacional.

Em maio, o Brasil já havia rejeitado uma proposta argentina, encaminhada ao Itamaraty pelo embaixador Oscar Camilion, para a realização de conversações trilaterais - portanto, com a inclusão do Paraguai - sobre a compatibilização dos projetos energéticos no rio Paraná. Na mesma época, Camilion levou a Silveira uma sugestão alternativa: conversações em nível estritamente técnico, apenas entre brasileiros e argentinos, sobre Itaipu e Corpus. ${ }^{20}$

O embaixador deixou o gabinete do chanceler sem levar consigo uma resposta diferente da que já conhecia - segundo o Ministério das Relações Exteriores, sobre Itaipu deveriam conversar brasileiros e paraguaios; sobre Corpus, paraguaios e argentinos. Agravou a situação o fato de, horas antes da audiência com Camilion, Azeredo da Silveira ter prestado depoimento sigiloso perante a Comissão de Relações 


\section{A Hidropolítica Platina no Contexto do}

Complexo Regional de Segurança...

Exteriores do Senado Federal sobre a questão da Bacia do Prata, ocasião em que ele teria formulado severas críticas à posição argentina.

De acordo com o semanário Ultima Clave, tido como porta-voz dos setores liberais do Exército argentino, na raiz das divergências sobre o rio Paraná estariam as "ambições hegemônicas" do Brasil no Cone Sul da América e a "estratégia expansionista baseada nos conceitos geopolíticos de fronteiras móveis e destino manifesto". O jornal sentenciou que "Itaipu, acima de tudo, é uma plataforma de lançamento da hegemonia brasileira na Bacia do Prata". As críticas mais contundentes do Ultima Clave também não pouparam a diplomacia portenha, que, segundo o periódico, não teria sido capaz de definir uma linha de ação coerente em face das ações do Brasil (apud A SOFRIDA..., 1977).

O ápice dessa tensa relação aconteceu em 31 de julho de 1977, quando a Argentina, supostamente em função das divergências quanto ao aproveitamento do rio Paraná, fechou sua fronteira com o Brasil. O túnel Las Cuevas-Caracoles, utilizado por brasileiros e chilenos como meio de ligação entre os dois países através da Argentina, foi fechado para o transporte de cargas rodoviárias provenientes do Brasil, obrigando, assim, os caminhões brasileiros, bem como os chilenos com destino ao Brasil, a fazerem um desvio de mais de 2 mil quilômetros. Esta atitude deu início a uma espiral de tensão (ainda que efêmera) movida por ações e reações de ambos os lados, confirmando, pois, a instabilidade da situação. ${ }^{21}$

Em nota oficial, o Itamaraty repudiou a iniciativa e alertou que estudava uma retaliação na mesma medida, possivelmente fechando a faixa lindeira entre Paso de los Libres e Uruguaiana para o transporte de carga oriunda da Argentina, o que serviu como pretexto para que a Casa Rosada respondesse à ameaça denunciando o Tratado de Amizade e Comércio, instrumento garante da livre navegação no rio da Prata desde 1856 (FAJARDO, 2004, p. 97). ${ }^{22}$ 
Como veremos adiante, tal quadro só alcançou um bom desfecho em 1979, com a celebração do Acordo Multilateral Corpus-Itaipu, tratado tripartite que normatizou o aproveitamento do rio Paraná entre Argentina, Brasil e Paraguai, finalizando, então, essa profunda crise.

\section{- Acordo Tripartite Corpus-Itaipu}

Ao assumir o governo em 15 de março de 1979, João Batista Figueiredo (1979-1985) anunciou como uma das orientações prioritárias de sua política externa - conceitualmente rotulada de Diplomacia do Universalismo $-{ }^{23}$ o fortalecimento dos laços com os países da América Latina e, em especial, com a Argentina. Para cumprir esse intento, Ramiro Saraiva Guerreiro, secretário-geral do Itamaraty na gestão anterior e, agora, chanceler, fora incumbido de conduzir, com máxima brevidade, a retomada das negociações com Buenos Aires sobre a exploração dos recursos hidrelétricos platinos.

Tal ação era considerada fundamental para remover as desconfianças que pairavam em relação ao Brasil e preparar, uma vez minimizadas velhas tensões, o cenário sobre o qual se conformaria, dali em diante, uma sociedade estratégica viabilizada pela construção de um poder compartilhado (jogo de soma positiva) em substituição ao combalido quadro de reequilíbrio e contenção (jogo de soma zero) (CANDEAS, 2005, p. 33).

E, de fato, foram pouco meses, menos de sete, desde a posse de Figueiredo até a celebrada assinatura do "Acordo sobre Cooperação Técnico-Operativa entre os Aproveitamentos de Itaipu e Corpus" pelos chanceleres Ramiro Saraiva Guerreiro, Carlos Washington Pastor (Argentina) e Alberto Nogues (Paraguai), em 19 de outubro de 1979, em Ciudad Presidente Stroessner. Como dissera o próprio chanceler:

Em poucos meses, em outubro de 1979, assinávamos com a Argentina e o Paraguai o acordo 


\section{A Hidropolítica Platina no Contexto do Complexo Regional de Segurança...}

tripartite de compatibilização de Itaipu e Corpus. Punha-se fim definitivamente a uma controvérsia com a Argentina, que azedava as relações bilaterais havia onze anos. Sem a eliminação dessa controvérsia, não teria sido possível desenvolver as relações com a Argentina no grau de intensidade e confiança mútua que as caracterizou no governo Figueiredo e criou as bases para seu incremento sucessivo em governos sucessivos (GUERREIRO, 1992, p. 91-92).

Em outras palavras, a assinatura desse instrumento foi fator fundamental para a mudança de rumo nas relações argentino-brasileiras ao estabelecer as variações permitidas para Corpus e Itaipu, colocando, então, fim ao impasse em torno dos projetos para o aproveitamento hidrelétrico no rio Paraná, ajudando, assim, na obtenção de resultados mais eficientes. Consequentemente, o acordo agiu como liame de aproximação e, ao mesmo tempo, de rompimento de um perfil disfuncional que dominou, por mais de um século, o cenário hidropolítico platino, levando, enfim, os dois rivais à revisão das regras do jogo em suas relações internacionais.

Dessa forma, com a diversificação de parceiras como um dos pilares de sua política externa, ao Brasil de Figueiredo não interessava uma Argentina desindustrializada ou economicamente debilitada já que, nesse contexto de reaproximação, em seu plano de inserção internacional, o país precisava de um parceiro estratégico forte, com o qual pudesse contar para se projetar a partir de um cenário de integração (CANDEAS, 2005, p. 33; OLIVEIRA, 2005, p. 199).

A Argentina, por sua vez, reconheceu as limitações de sua capacidade de atuação e a importância da cooperação com o Brasil (OLIVEIRA, 1998, p. 13). Tal cenário contribuiu, sobremodo, para arrefecer rivalidades e tensões remanescentes causadas pelo (des)equilíbrio de poder sub-regional. Concomitantemente, fortaleceu-se a confiança mútua, tornou-se anacrônica a hipótese de um conflito armado 
e inaugurou-se uma nova fase no relacionamento entre os dois países, marcada pela construção de uma estabilidade estrutural pela via da cooperação (CANDEAS, 2005, p. 23).

Já o Paraguai, grandemente beneficiado com o desfecho da situação, soube explorar muito bem a complexa dualidade estratégica de sua política pendular, ratificando, pois, a privilegiada condição do país que tinha - e ainda tem - nos recursos hídricos uma poderosa moeda política.

Portanto, com base nos fatos narrados, podemos concluir que o Acordo Tripartite Corpus-Itaipu representou um ponto de inflexão entre a disputa geopolítica e a construção de uma gestão cooperativa na Bacia do Prata, abrindo, assim, espaço para que ao longo das duas décadas seguintes tomasse forma um amplo e gradual projeto de integração entre os países do Cone Sul tendo como principal eixo definidor a revisão das relações entre Brasília e Buenos Aires (KEMPKEY et al., 2009).

Em outras palavras, enquanto as décadas de 1960 e 1970 ficaram marcadas pelo clima de tensão prevalecente nas relações entre Brasil e Argentina, suscitando, inclusive, muitas dúvidas quanto à viabilidade de um processo de integração no Cone Sul, nas décadas seguintes - 1980 e 1990 - consolidou-se a emergente estabilidade estrutural iniciada com o Acordo Tripartite Corpus-Itaipu e a consequente dessecuritização progressiva da hidropolítica platina. ${ }^{24}$

\section{Conclusões}

Os argumentos discorridos ao longo dessas páginas demonstraram que a hidropolítica internacional se encontra fortemente associada às relações de interdependência que se estabelecem entre aqueles atores que compartilham os recursos de um sistema hidrográfico e/ou sofrem os efeitos transfronteiriços decorrentes de seu uso, o que evi- 


\section{A Hidropolítica Platina no Contexto do}

Complexo Regional de Segurança...

dencia uma intrínseca ligação com a lógica da adjacência (territorialidade).

O Complexo Regional de Segurança da América do Sul ratifica essa constatação. A região destaca-se no plano internacional como um grande condomínio hídrico por ostentar em seus domínios importantes bacias hidrográficas, entre elas a Bacia do Prata, uma das principais do planeta. Por isso, como pressupõem os fatos históricos, ela ocupa papel de destaque como assunto estratégico nas relações internacionais da região e, concomitantemente, na definição da agenda de segurança desse espaço.

O recorte temporal abordado neste artigo (1960-1979) demonstrou a validade das assertivas citadas, a complexidade do tema e, também, sua natureza ambivalente. Assim, considerando-se a condição de tensão prevalecente no período - apesar da existência de intermitências temporais de instabilidade conjuntural entremeadas com a busca pela cooperação (1960-1973) -, a análise dos fatos apresentados nos permitiu constatar a existência de um Complexo Hidropolítico de Segurança na Bacia do Prata, arranjo estrutural que prevaleceu até 1979.

Após a resolução do contencioso Corpus-Itaipu, ainda que alternando avanços e retrocessos, houve, como apontado, a progressiva dessecuritização da hidropolítica platina que, em consonância com uma série de outros fatores ulteriores ao acordo tripartite, ${ }^{25}$ contribuiu para a construção de uma sociedade estratégica baseada na institucionalização de um projeto de poder compartilhado que lançou as bases de uma nova etapa nas relações internacionais da América do Sul.

Logo, a prevalência da estabilidade estrutural a partir de 1979 permite-nos qualificar a Bacia Platina, outrora um CHS, como um Complexo Hidropolítico estável, ainda que entreveros tenham surgido recentemente - como o caso das "papeleras" no rio Uruguai e a reivindicação paraguaia pela revisão do Tratado de Itaipu,$-{ }^{26}$ mas, ressal- 
te-se, todos eles sendo resolvidos por meio dos processos usuais de negociação e resolução de controvérsias, o que confirma a dessecuritização do tema, via de regra, como a resultante de um padrão comportamental cooperativo prevalecente entre os atores que integram o Subcomplexo de Segurança do Cone Sul.

Desta maneira, o estudo de caso proposto demonstrou a validade do argumento de que a identificação de ameaças, bem como a construção de identidades entre os atores que integram esses espaços comunais, resulta de processos sociais baseados em interpretações e conexões cognitivas originadas, em grande medida, das relações históricas de amizade/inimizade que se desenvolvem em decorrência do aproveitamento compartilhado dos recursos de um complexo hidrográfico.

Eis, então, a síntese da rationale que define o modelo teórico do Complexo Hidropolítico da Bacia do Prata. Amparada nos vínculos simbióticos estabelecidos entre os elementos ontológicos que integram tal estrutura, ela é a resultante de um notável grau de interdependência hidrológica que inevitavelmente os conecta em um enredo multissetorial altamente politizado, efeito de um contexto prevalecente de cooperação observável, sobretudo, a partir dos anos 1980, quando houve a significativa remoção dos constrangimentos decorrentes de um longo período de antagonismos e desconfianças.

Por fim, faz-se importante abrir um breve espaço para tratar de alguns fatores capazes de agregar novas nuances ao estudo da hidropolítica platina, mas que, neste artigo, em razão dos limites estabelecidos para o estudo, não foram abordados. São eles: os efeitos das mudanças climáticas sobre a quantidade e a qualidade dos recursos hídricos; o papel dos mananciais subterrâneos na formação de Complexos Hidropolíticos; e a atribuição de valor à água utilizada na produção de bens para exportação - a chamada água virtual. Vamos, então, a algumas sucintas considerações acerca dos temas citados. 


\section{A Hidropolítica Platina no Contexto do Complexo Regional de Segurança...}

Primeiramente, é uníssona a assertiva de que compreender os riscos inerentes às mudanças climáticas constitui um dos eixos permanentes da agenda do século XXI e, igualmente, um dos temas complexos pelos quais perpassam as relações internacionais contemporâneas. Assim, entender seus efeitos, por exemplo, na regularidade dos períodos de chuva e seca e, por conseguinte, na regulação do sistema hidrelétrico pode ser um fator determinante nos movimentos de securitização da hidropolítica platina.

De igual maneira, considerar a água virtual como objeto de análise traz aspectos relevantes ao debate. Essencialmente, esse termo diz respeito ao comércio indireto da água envolvida no processo produtivo de bens industriais e, especialmente, de commodities agrícolas.

O principal dividendo a ser auferido com a incorporação desse conceito estaria em verificar em que medida o comércio internacional de bens intensivos em uso de recursos hídricos seria capaz de estabelecer sobreposições verticais (entre os Complexos Hidropolíticos e potências exógenas a eles) e/ou horizontais (intra e inter Complexos Hidropolíticos), abrindo, assim, espaço para novas possibilidades ao irromper-se, por exemplo, a lógica da adjacência. Essa perspectiva é interessante, sobretudo, para a América do Sul, grande exportadora de commodities e um dos maiores reservatórios de água doce do mundo.

Por último, considerando que as águas subterrâneas, ou aquíferos, representam a única fonte de água potável para quase $1 / 4$ da população mundial e que também respondem por cerca de $50 \%$ do suprimento total dos recursos hídricos utilizados no abastecimento público e $40 \%$ e $20 \%$ da água empregada, respectivamente, na indústria e na irrigação (CLARKE; KING, 2005, p. 26), entender as implicações multissetoriais produzidas pelo uso compartilhado de uma das maiores reservas subterrâneas de água doce do mundo, o Aquífero Guara- 
ni, apresenta-se como uma variável relevante na definição das dinâmicas que dão forma ao Complexo Hidropolítico da Bacia do Prata.

\section{Notas}

1. O termo hidropolítica é aqui empregado para designar o conjunto de ações de identificação e resolução de demandas resultantes da percepção de que os recursos hídricos e seus múltiplos usos atuam como um importante componente para a estabilidade geopolítica de um dado espaço: sejam Estados ribeirinhos, regiões, comunidades ripícolas ou outros agrupamentos que tenham nesse recurso um elemento estratégico, inclusive em termos de segurança.

2. Esta e as demais citações de originais em língua estrangeira foram livremente traduzidas para este artigo.

3. Em Security: A New Framework for Analysis (1998), Barry Buzan, Ole Wæver e Jaap de Wilde adotam como alternativa para a ampliação conceitual o alargamento da agenda de segurança de forma a permitir a inclusão de ameaças outras que não apenas aquelas advindas dos tradicionais setores político e militar, mas também da área ambiental, societal e econômica, cada qual com suas dinâmicas, contudo, mantendo os atributos que qualificam um dado assunto como sendo de segurança: ameaça percebida como risco potencial à sobrevivência de um objeto referente; caráter de urgência; e o poder estatal reivindicando o uso legítimo de meios extraordinários para enfrentar o problema.

4. Daí o grupo de Copenhague utilizar a definição de região como um espaço territorialmente coerente composto por dois ou mais Estados, porquanto a presença regular dessa unidade de análise em qualquer setor que se analise proporciona, extensivamente, consistência e densidade ao modelo dos CRS.

5. Tal qual definido por DEUTSCH (1957), Comunidades de Segurança são compostas por Estados que compartilham valores fundamentais e adaptam seus comportamentos a princípios, normas e instituições comuns e a processos conjuntos de decisão em nome de um convívio pacífico. Este conceito foi recuperado por Adler e Barnett (1998), que a ele incorporaram elementos construtivistas como o papel das identidades compartilhadas. Estas comunidades podem dar forma a um novo ente político (comunidades amalgamadas), como ocorreu no processo de unificação alemã, ou manter seus membros como unidades independentes (comunidades pluralistas), como é hoje a União Europeia. Em ambos 


\section{A Hidropolítica Platina no Contexto do Complexo Regional de Segurança...}

os casos, as Comunidades de Segurança são notadamente marcadas por processos de dessecuritização.

6. Alguns CRS, geralmente aqueles em que há um grande número de atores, contêm arranjos intermediários denominados subcomplexos. Essas estruturas sub-regionais apresentam essencialmente os mesmos atributos que definem um CRS, entretanto seus padrões de interdependência em segurança diferem uns dos outros. Ainda assim, tais dinâmicas estabelecem entre os subcomplexos correlações e sobreposições intensas ao ponto de não permitir que os mesmos sejam desassociados daquela estrutura mais ampla da qual são parte integrante.

7. Atualmente, a Usina de Três Gargantas, na China, é a maior do mundo em potência instalada (18 mil MW contra 14 mil MW de Itaipu), mas não em geração de energia. Sua capacidade é de 86,7 bilhões de kWh anuais contra 90 bilhões de kWh de Itaipu (PINTO, 2009, p. 18).

8. Na verdade, a navegação manteve sua proeminência praticamente durante toda a primeira metade do século XX, como evidenciou a Conferência Regional dos Países do Prata realizada em Montevidéu (jan./fev. 1941), uma das primeiras tratativas contemporâneas a abordar o tema da exploração integrada da Bacia Platina. Nela, aprovou-se uma resolução que previa a criação de comissões técnicas mistas para o estudo do sistema hidrográfico platino visando a promoção de melhorias nas condições de navegabilidade e a utilização de suas águas para fins industriais e agrícolas. Mesmo antevendo possibilidades outras de emprego dos recursos hídricos, o documento destacava, ostensivamente, a utilização dos rios platinos para fins navegacionais. Outro ponto correlato que merece ser citado, ainda que não tenha sido efetivamente alcançado, refere-se ao desafio lançado de se buscar a integração das três principais bacias fluviais sul-americanas: Prata, Amazonas e Orenoco (VILLELA, 1984, p. 149).

9. De acordo com o adendo encaminhado ao Ministério das Relações Exteriores por C. de Ouro Preto, o Beyoglu foi um veículo de difusão da propaganda alemã na Turquia na década de 1940, e sua redação dependia diretamente dos serviços de imprensa da Embaixada germânica. Portanto, no que se referia ao Brasil, o tom geralmente era "acrimonioso e acerbo" enquanto tudo que se referia à Argentina era "besuntado de mel de lisonja" (p. 1). Ainda de acordo com o diplomata, quanto ao artigo em apreço, talvez o articulista tenha previamente se aconselhado com membros da representação argentina no país antes de escrever sobre Sete Quedas/Saltos de Guairá, dadas a sensibilidade política do assunto e as possíveis repercussões que teriam tais declarações no Brasil (encaminhado ao Chanceler Oswaldo Aranha, em 31 de julho de 1944: MRE/AH, doc. n. 664.61 (30) ã DPD; Leg. Ankara/0.98/1944/anexo único). 


\section{Fábio Albergaria de Queiroz}

10. Informativo n. 2, AH/MRE: DE/664.62 (43), expedido em 01/09/1952. p. $1-2$.

11. Carta-telegrama expedida pela Embaixada em Assunção em 25/7/1952. AH/MRE: DE/664.62 (43).

12. O setor produtivo brasileiro vinha em ritmo acelerado de crescimento desde o governo de Juscelino Kubitschek (1956-1961). Com o lançamento da Operação Pan-Americana (OPA), reflexo das novas necessidades da economia brasileira, a política externa de JK entra em sua segunda fase (jul./1958-jan./1961), notadamente marcada por não mais buscar uma relação privilegiada com os Estados Unidos, mas o desenvolvimento econômico por meio da industrialização, diversificação da pauta de exportação e conquista de novos mercados.

13. O Barão de Cotegipe, após a Guerra do Paraguai (1864-1870), instituiu um protocolo, de caráter emergencial e carente de precisão geográfica, como forma de resolver, ainda que precariamente, os problemas fronteiriços pendentes entre os beligerantes. No caso de Brasil e Paraguai, a principal disputa referia-se à posse de Sete Quedas/Saltos de Guairá, como era conhecida a região, respectivamente, por brasileiros e paraguaios. Por isso, haveria a necessidade de se instituir outro documento para servir como base dos limites fronteiriços permanentes entre os dois contendores. No entanto, até meados do século XX, as duas Chancelarias não resolveram efetivamente a questão de fronteiras, preservando certa medida de incerteza, apesar de sua visível centralidade para o equilíbrio de poder na América do Sul.

14. Otávio Marcondes Ferraz (1896-1990), à época a maior autoridade do país em energia hidráulica, foi nomeado presidente da Eletrobrás em 28 de abril de 1964, função que exerceu até 1967. Engenheiro de renome internacional, Ferraz foi autor e coordenador do projeto de Paulo Afonso I no rio São Francisco, empreendimento inaugurado em 1955. Foi também ministro da Viação e Obras Públicas no governo Café Filho (1954-1956).

15. Telegrama encaminhado pela Embaixada em Assunção ao Ministério das Relações Exteriores, em caráter secreto e urgentíssimo, em 27/04/1966. MRE/AH: AAA/DAM/DF, n. 102.

16. Considerando-se um ponto referencial qualquer em relação a um curso d'água transfronteiriço, tal ponto, quanto à sua localização em relação a este fluxo, será definido como estando a sua montante ou jusante. Esses conceitos são relevantes uma vez que se relacionam não apenas com a noção de posição e localização, mas igualmente com elementos tradicionais das relações internacionais (conflito, cooperação, equilíbrio de poder e, claro, segurança), que, por sua natureza, atuam como forças motrizes na definição da geopolítica das 


\section{A Hidropolítica Platina no Contexto do Complexo Regional de Segurança...}

águas, o que faz das locuções "a montante" e "a jusante" elementos basilares na elaboração dos argumentos que darão forma ao ato-discurso no campo da hidropolítica. Assim, tudo que se encontra acima do ponto de referência subindo a correnteza do rio se diz que se situa a montante (rio acima), enquanto tudo que está localizado entre ele e a foz se situa a jusante do ponto de referência, ou seja, rio abaixo.

17. Tal proposta se consumou quase um ano depois, quando Illia já não era mais presidente por ter sido deposto pelo golpe militar liderado pelo general Juan Carlos Onganía, em 28 de junho de 1966, no episódio que ficou conhecido como Revolução Argentina. Assim, a I Reunião dos Chanceleres da Bacia do Prata veio a acontecer somente em janeiro de 1967.

18. Tanto a Ata como o Tratado de Itaipu dispõem que a energia não utilizada por um dos condôminos só poderá ser negociada com o outro, a preços justos. Como o Paraguai utiliza apenas 5\% do montante que lhe cabe, toda a energia remanescente é vendida ao Brasil.

19. Evidentemente, como dito, havia correntes contrárias à construção de Itaipu. Dentre seus arautos, destacava-se Domingo Laino, principal liderança oposicionista à Stroessner. Seu discurso securitizador apontava o crescimento brasileiro, somado à política "entreguista" de seu desafeto político, como uma séria ameaça à soberania paraguaia. A resultante dessa perigosa combinação, acusava Laino, podia ser facilmente comprovada ao observar-se a compra massiva de terras na faixa de fronteira por brasileiros, espaço estratégico onde o português começava a prevalecer como idioma (PINTO, 2009, p. 109).

20. Enquanto em Buenos Aires havia o temor de que Itaipu pudesse transtornar a navegação e os portos argentinos rio abaixo, na medida em que provocaria bruscas oscilações no nível das águas, Brasília, por sua vez, entendia que a construção de Corpus na cota de 120 metros acima do nível do mar, considerada ideal pelos argentinos, "afogaria" com seu reservatório as turbinas de Itaipu reduzindo em cerca de 1/6 sua capacidade de produção energética.

21. A justificativa apresentada pelas autoridades argentinas para a aplicação do bloqueio era de que os caminhoneiros brasileiros se recusavam a pagar uma compensação tarifária pelo uso da infraestrutura do país, no caso o túnel, conforme previsto em um convênio provisório de transporte terrestre internacional celebrado pelos três países mais o Uruguai e o Paraguai. Segundo o documento, além das taxas de compensação pelo uso de seu sistema rodoviário, o país que servia como ponte de ligação entre outros dois Estados tinha também o direito de fixar os itinerários das empresas transportadoras que o utilizavam. Apesar das citadas garantias jurídicas, o Brasil alegou que a medida só foi executada 


\section{Fábio Albergaria de Queiroz}

por conta das divergências existentes entre os dois países sobre os projetos hidroenergéticos em curso no rio Paraná.

22. Apesar da manobra argentina, a intenção brasileira demonstrou não passar de uma precavida escaramuça diplomática, tanto que, para evitar maiores transtornos, o Itamaraty optou em não adotar qualquer medida retaliatória pelo ocorrido e, assim, as licenças temporárias concedidas pelo Departamento Nacional de Estrada e Rodagem (DNER) para que os caminhões argentinos pudessem cruzar a fronteira brasileira, com validade expirando em 31 de julho daquele ano, foram todas automaticamente renovadas.

23. Entre as premissas básicas da política externa de Figueiredo, estavam medidas como: a) a busca de maior autonomia e espaço para a atuação diplomática do Brasil, sobretudo por meio de um maior distanciamento dos EUA. Com isso, pretendeu-se refutar a tese do key-country, concepção segundo a qual os EUA delegariam a um país-chave, em cada área estratégica, o mandato para manter a ordem e a estabilidade da Pax Americana, sendo o Brasil o escolhido para exercer este papel na América do Sul (OLIVEIRA, 2005, p. 197); b) a diversificação do diálogo com diferentes países, de acordo com as necessidades e aspirações brasileiras. Neste sentido, buscou-se o estreitamento dos vínculos políticos e econômicos com a América Latina e evitaram-se alinhamentos automáticos; e c) a inserção do país com igual equilíbrio em duas esferas de atuação: o Ocidente e o Terceiro Mundo.

24. No plano político-estratégico-militar, alguns acontecimentos foram fundamentais para concretizá-la e, também, confirmar a mudança de percepção nas relações entre os dois países: a celebração do Acordo de Cooperação para Desenvolvimento e Aplicação dos Usos Pacíficos da Energia Nuclear (1980), a declaração brasileira de apoio a Buenos Aires durante a Guerra das Malvinas (1982) e o início do processo de redemocratização e restauração dos governos civis em meados dos anos 1980. Na sequência dos acontecimentos, o efeito spillover desse processo se desdobrou exitosamente para o campo econômico, atingindo seu ápice em 1991, com a criação do Mercado Comum do Sul.

25. Em especial, a construção da confiança na área nuclear entre Brasil e Argentina e a constituição de um projeto de integração bilateral que, a partir de um enfoque gradualista e flexível, ao incrementar o intercâmbio comercial entre ambos com iniciativas como o Programa de Integração e Cooperação Econômica (PICE/1986) e a celebração, em 1988, do Tratado de Integração, Cooperação e Desenvolvimento, que previa a constituição de um espaço econômico comum no prazo de dez anos, logo se estendeu exitosamente a outros países do Cone Sul. 


\section{A Hidropolítica Platina no Contexto do Complexo Regional de Segurança...}

26. O chamado "caso das papeleras" refere-se ao notório contencioso envolvendo Argentina e Uruguai por ocasião da construção de duas usinas de papel e celulose na fronteira entre os dois países, às margens do rio Uruguai. O ponto do desentendimento decorreu de o Uruguai ter autorizado a empresa espanhola ENCE S.A. e a finlandesa Oy Metsä-Botnia Ab (Botnia) a iniciarem a construção de suas fábricas em Fray Bentos, cidade limite da jurisdição territorial uruguaia, sem seguir o procedimento estabelecido pelo Estatuto do Rio Uruguai (1975), que prevê o mecanismo de informação e consulta prévia (art. $7^{\circ}$ ) no caso de obras capazes de produzir efeitos transfronteiriços. Submetido à apreciação da Corte Internacional de Justiça (CIJ), o caso teve seu desfecho em 20 de abril de 2010, quando a tão aguardada decisão veio a público. Por treze votos a um, a Corte entendeu que o Uruguai violou o Estatuto de 1975 ao não consultar a Argentina antes da instalação das usinas, devendo o país, portanto, assumir a responsabilidade por eventuais danos causados ao meio ambiente. Entretanto, a CIJ deliberou, por onze votos a três, que o Uruguai, até o momento, não havia descumprido o tratado no que tange à proteção do meio ambiente, tendo em vista que o nível de poluição no rio Uruguai não aumentou após a instalação das indústrias. Assim, para a frustração de Buenos Aires, a decisão da CIJ não alterou em absolutamente nada o status quo da situação. Já no caso do imbróglio envolvendo Itaipu, o Paraguai exigiu, a partir da eleição de Fernando Lugo em abril de 2008, a revisão do preço pago pela energia excedente repassada ao Brasil por força do Tratado e, concomitantemente, o direito de vendê-la a terceiros, a preço de mercado. Para tanto, Assunção reeditou velhas propagandas como as que rotulavam o Brasil de imperialista e aventureiro belicoso, e Itaipu de instrumento de espoliação que teria, como fim, subjugar o Paraguai ao domínio brasileiro. Como resultado, o Brasil aceitou um reajuste de $200 \%$ no preço pago pela energia paraguaia e também concordou em auxiliar financeiramente o Paraguai em uma série de projetos de infraestrutura, como a estruturação de uma linha de transmissão de 350 km ligando Itaipu a Assunção.

\section{Referências Bibliográficas}

A SOFRIDA procura da paz. Veja, 27 jul. 1977. Disponível em: <http://veja. abril.com.br/arquivo_veja/capa_27071977.shtml>. Acesso em: jul. 2010.

ADLER, Emanuel; BARNETT, Michael (Ed.). Security Communities. Cambridge: Cambridge University Press, 1998. 
ALLAN, J. A. The Middle East Water Question. Hydropolitics and the Global Economy. Londres: I. B. Tauris \& Co., 2001.

Water resources in semi-arid regions: real deficits and economically invisible and politically silent solutions. In: TURTON, A. R.; HENWOOD, E. (Ed.). Hydropolitics in the Developing World: A Southern African Perspective. Pretória: African Water Issues Research Unit (AWIRU), 2002. p. 23-36.

ANA - Agência Nacional de Águas. Bacias brasileiras do Rio da Prata: avaliações e propostas. Brasília: ANA, 2001.

BUZAN, Barry. People, States and Fear: An Agenda for International Security in the Post-Cold War Era. Chapel Hill: University of North Caroline, 1991.

BUZAN, Barry; WÆVER, Ole. Regions and Powers: The Structure of International Security. Cambridge: Cambridge University Press, 2003.

; WÆVER, Ole; DE wilde, Jaap. Security: A New Framework for Analysis. Londres: Lynne Rienner Publishers, 1998.

CANDEAS, Alessandro Warley. Relações Brasil-Argentina: uma análise dos avanços e recuos. Revista Brasileira de Política Internacional, Brasília, v. 48, n. 1, jun. 2005. Disponível em: <http://www.scielo.br/scielo.php?script= sci_arttext\&pid=S0034-73292005000100007\&lng=en\&nrm=iso $>$. Acesso em: 21 ago. 2010.

CAUBET, Christian G. As grandes manobras de Itaipu: energia, diplomacia e direito na Bacia do Prata. São Paulo: Acadêmica, 1989.

A água doce nas relações internacionais. São Paulo: Manole, 2006.

CLARKE, Robin; KING, Jannet. O atlas da água. São Paulo: Publifolha, 2005.

DEUTSCH, Karl. Political Community and the North Atlantic Area. Princeton: Princeton University Press, 1957.

ELHANCE, Arun P. Hydropolitics in the Third World: Conflict and Cooperation in International River Basins. Washington: US Institute of Peace, 1999.

FAJARDO, José Marcos Castellani. Acordo Tripartite Itaipu-Corpus: ponto de inflexão entre a disputa geopolítica e a política de cooperação. Dissertação (Mestrado em Ciência Política) - Universidade Federal do Rio Grande do Sul, Porto Alegre, 2004. 


\section{A Hidropolítica Platina no Contexto do Complexo Regional de Segurança...}

FERREIRA, Luís. Ano Internacional da Água Doce: repensar a hidropolítica no contexto da segurança regional. Negócios Estrangeiros. Lisboa: IPRIS, n. 6, p. 39-60, dez. 2003.

GUERREIRO, Ramiro Saraiva. Lembranças de um empregado do Itamaraty. São Paulo: Siciliano, 1992.

ITAIPU: un hito en el desarrollo del Paraguay. Naande, s/n, 1973. [Disponível no Arquivo Histórico do MRE].

KEMPKEY, Natalie; PINARD, Margaret; POCHAT, Victor; DINAR, Ariel. Negotiations over water and other natural resources in the La Plata River Basin: a model for other transboundary basins? International Negotiation, v. 14, n. 2, p. 253-279, 2009.

KEOHANE, Robert O. After hegemony: cooperation and discord in the world economy. Princeton: Princeton University Press, 2005.

; NYE, Joseph. Power and Interdependence. 2. ed. Nova Iorque: Harper Collins Publishers, 1989.

LE PRESTRE, Philippe. Ecopolítica internacional. São Paulo: Senac, 2000.

LES RESERVES de force hydraulique de l'Amérique Du Sud: de grands projects ont été établis pour leur exploitation. Beyoglu, 28 jul. 1944.

LIMA, Maria Regina Soares de. The Political Economy of Brazilian Foreign Policy: Nuclear Energy, Trade and Itaipu. Dissertação (Ph.D em Ciência Política) - Vanderbilt University, Nashville, 1986.

OLIVEIRA, Henrique Altemani. Política externa brasileira. São Paulo: Saraiva, 2005.

OLIVEIRA, Odete Maria de. A integração bilateral Brasil-Argentina: tecnologia nuclear e Mercosul. Revista Brasileira de Política Internacional, Brasília, v. 41, n. 1, p. 5-23, 1998.

PECEQUILO, Cristina; HAGE, José Alexandre. Dilemas sul-americanos: o Brasil, o Paraguai e Itaipu. Meridiano 47, Brasília, 2007. Disponível em: <http://meridiano47.info/2007/07/19/190720071526/>. Acesso em: ago. 2010.

PEREIRA, Osny Duarte. Itaipu: prós e contras. Rio de Janeiro: Paz e Terra, 1974. 
PINTO, Tão Gomes. Itaipu: integração em concreto ou uma pedra no caminho? São Paulo: Manole, 2009.

SCHULZ, Michael. Turkey, Syria and Iraq: A Hydropolitical Security Complex. In: OHLSSON, Leif (Ed.). Hydropolitics: Conflicts over Water as a Development Constraint. Londres: Zed Books, 1995.

STAHL, Bernhard. Who Securitized what, when, and how? A Comparative Analysis of Eight EU Member States in the Iraq Crisis. Trabalho apresentado na conferência do European Consortium for Political Research (ECPR) em Turim, set. 2007.

TURTON, Anthony R. Hydropolitics and Security Complex Theory: An African Perspective. Trabalho apresentado na 4- Pan-European International Relations Conference, University of Kent, Canterbury (Reino Unido), 8-10 set. 2001. Disponível em: <http://www.up.ac.za/academic/libarts/polsci/awiru>. Acesso em: 20 mar. 2009.

. The Political Aspects of Institutional Developments in the Water Sector: South Africa and its International River Basins. Tese (Ph.D. em Política Internacional) - Universidade de Pretória, Pretória, África do Sul, 2003. Disponível em: <http://upetd.up.ac.za/UPeTD.htm>. Acesso em: 26 mai. 2009.

A South African Perspective on a Possible Benefit-Sharing Approach for Transboundary Waters in the SADC Region. Water Alternatives, v. 1, n. 2, p. 180-200, 2008.

UGARTE: Itaipu cambiará la historia económica. La Tribuna, 20 mar. 1973.

UM ENTENDIMENTO inevitável. Veja, 11 abr. 1973. Disponível em: $<$ http://veja.abril.com.br/arquivo_veja/capa_11041973.shtml>. Acesso em: jul. 2010.

UNEP - United Nations Environmental Program. Atlas of International Freshwater Agreements. 2002. Disponível em: <http://www.transboundarywaters.orst.edu/publications/atlas $>$. Acesso em: jan. 2007.

VILLELA, Anna Maria. O Tratado da Bacia do Prata. Revista de Informação Legislativa, Brasília, ano 21, n. 81, Suplemento, p. 147-176, jan./mar. 1984.

WWF. World's Top 10 Rivers at Risk. Gland: WWF International, 2007. 


\section{A Hidropolítica Platina no Contexto do Complexo Regional de Segurança...}

\section{Resumo}

\section{A Hidropolítica Platina no Contexto do Complexo Regional de Segurança da América do Sul: Entre o Conflito e a Cooperação (1960-1979)}

Em várias regiões do mundo, os múltiplos usos de águas compartilhadas apresentam-se como um componente importante no jogo de poder regional. Essa situação explica por que a gestão de recursos hídricos se encontra vinculada a preocupações de ordem estratégica ou outras questões de alta política em muitos desses casos. Mas em que intensidade? Em busca de respostas para essa questão, o presente estudo analisa o caso da Bacia do Prata, empregando, para tanto, conceitos como securitização, atores securitizadores, objetos de referência, Complexos Regionais de Segurança (CRS) e, também, a ideia dos Complexos Hidropolíticos, originalmente desenvolvida por Michael Schulz como uma forma distinta de CRS aplicável em áreas onde as questões relacionadas aos recursos hídricos se destacam como uma característica proeminente nas dinâmicas políticas regionais.

Palavras-chave: Hidropolítica - Bacia Platina-Complexo HidropolíticoSegurança Internacional

\section{Abstract}

\section{Hydropolitics in the River Plate Basin in the Context of the South American Regional Security Complex: Between Conflict and Cooperation (1960-1979)}

In many regions of the world, the multiple uses of transboundary fresh water have been seen as a critically important component for regional stability. This situation explains why, in many cases, water management has commonly become linked to national security concerns or other issues of a "high politics" nature. But, at what intensity? In search of answers for this question, this research analyzes the case of the River Plate Basin employing Barry Buzan's central concepts of securitization, securitizing 
Fábio Albergaria de Queiroz

actors, referent objects, Regional Security Complex (RSC) and the related concept of Hydropolitical Complex (HC) developed by Michael Schulz as a distinct form of RSC applicable on areas where water-related issues stand out as a salient feature in regional political dynamics.

Keywords: Hydropolitics - River Plate Basin - Hydropolitical Complex International Security 